\title{
A Comparison between Word Tree Branch Method and Interactive Word Wall to Improve Student's Vocabulary
}

\author{
Ribka Purnamasari, Caroline V Katemba, Nelson Panjaitan \\ Correspondence author: Caroline (linakatemba@gmail.com) \\ Universitas Advent Indonesia
}

\begin{abstract}
The purpose of this study is to find out the improvement of students' vocabulary between those who were taught through WTB (Word Tree Branch) or IWW (Interactive Word Wall). This study used quantitative research method and comparative design by using pre-test and post-test. This study was designed to find out the answer to the following question: Is there any significant difference on the students' vocabulary improvement between those who were taught through Word Tree Branch method and those who were taught through Interactive Word Wall method? The sample of this study are, two classes in grade VIII of SMPN 1 Parongpong, Bandung. They were divided into two classes, grade VIII H experienced Interactive word Wall and grade VIII J experienced Word Tree Branch. The instrument used for this study is vocabulary test, which contain 40 questions. The result of this study shows that the students who acquire WTB or IWW method were improved for their vocabulary, vocabulary categorized as "moderate" but there is no significant difference between those two groups of students 'vocabulary improvement.
\end{abstract}

Keywords: WTB (Word Tree Branch) and IWW (Interactive Word Wall) 


\section{INTRODUCTION}

English is an essential language to be learnt in order to meet the communication needs in this globalization era. Taking into account the benefits of English, Indonesia has established English as a subject to be taught in formal schools as a compulsory subject. As stated by Kemendikbud (2013), the teaching of foreign language especially English is a goal to develop students' ability to communicate to the world. In teaching English includes the teaching of four skills, listening, speaking, reading, and writing. Vocabulary is one of crucial aspects to support those skills. According to Richards and Renandya (2002), vocabulary is a core component of language ability and provides of the basis of how well students listen, speak and write.

Vocabulary knowledge is not only the key to improving reading comprehension but it also helps learners improve writing and speaking skills (Fitzgibbon, 2003). It means that, vocabulary greatly affects the development in learning language. When someone has extensive knowledge of vocabulary, it increases their academic talent listening, speaking, reading, and writing. Through studying vocabulary, the students will gain more knowledge and information faster.

Muttahidah (2011) said that students in Indonesia have problem in learning English vocabulary. The problems are the students cannot understand the meaning, difficult to pronounce the vocabulary, cannot understand how to connect one word to other words and hard to memorize.

Another reason about the case above, Plinscar and Brown (1985) said that there has a relationship between vocabulary knowledge and reading comprehension. In addition to that, Nurmayanti (2013) stated that in enhancing vocabulary, students should read a lot and understand the meaning; however, processing elements of vocabulary leads them to lose interest in having in-depth learning (Nurmayanti, 2013).

To solve that challenge, teacher should vary their methods in helping their students enhance their vocabulary knowledge. There are two methods that are considered effective to enhance students' vocabulary knowledge; they are: Word Tree Brach and Interactive Word Wall. Both of these methods have proven that those methods have been able increased the students' vocabulary knowledge.

Gede (2013) conducted his study entitled "Improving vocabulary Mastery through Word Tree Branch Techniques at Seventh Grade students of SMPN 1 Bebandem.” The result of his study stated that Word Tree Branch is an effective method to improve students Vocabulary mastery. Moreover, through this method his students become more enthusiastic, creative, active in learning.

While another method, Interactive Word Wall, was conducted by Elisa (2014) entitled "Improving English Vocabulary through Interactive Word Wall Method. Her study was successfully conducted because it was shown in the mean result in which students' vocabulary knowledge was increased. Another researcher named Henrichs 
(2011) conducted a similar study on Word Wall. He declared that Word Wall Method is an imperative method to enhance students' vocabulary mastery.

Therefore, this study was conducted to compare the two methods: Word Tree Branch Method and Interactive Word Wall and find their significant difference in improving students' vocabulary mastery.

\section{Statement of the problems}

This study focused on finding out the answer this question, 'Is there any significant difference of students' vocabulary improvement between those who were taught using Word Tree Branch Method and those who were taught using Interactive Word Wall method?'

\section{Purpose of the Study}

The purpose of the study is to improve students' vocabulary mastery by finding the significant difference between Word Tree Branch Method and Interactive Word Wall.

\section{Hypothesis}

Based on the problems above, the researcher provided the hypothesis as follow:

\section{Ho: Null Hypothesis}

There is no significant difference of students' vocabulary improvement between those who were taught using Word Tree Branch Method and those who were taught using Interactive Word Wall.

\section{Ha: Alternative Hypothesis}

There is a significant difference of students' vocabulary improvement between those who were taught using Word Tree Branch Method and those who were taught using Interactive Word Wall.

\section{Scope and limitation of the Study}

This study was conducted at SMPN 1 Parongpong, Bandung with total respondents 76. The methods compared in this study were Word Tree Branch and Interactive Word Wall to improve students' vocabulary mastery. The vocabulary knowledge given to the respondents was related to Parts of Speech, such as Noun, Verb, Adjective, and Pronoun. The research used Language Focus for grade 8 as the learning material. 


\section{REVIEW OF RELATED LITERATURE}

\section{Vocabulary Knowledge}

Reading and listening comprehension, speaking and writing fluency are the important factor of word meaning and the ability to access the knowledge efficiently. McKeown (2002) argued that the heart of a language comprehension and use is vocabulary knowledge. Additionally, Barra (2005) suggests that students need to have sufficient word knowledge to comprehend a text successfully. It means that the comprehension of a language depends on the amount of words that are known in language. Also, to know what the students read, they need to have sufficient word knowledge. Students can understand a message from writer if they know the meaning of most of the words used in a text.

In addition, Vocabulary will help students through language production. According to Hubbard (1983), students can express the exact meaning according to what they want if they have more words. Based on this view, students need to know a large number of word meanings to communicate effectively. So, students need to overcome their lack of vocabulary knowledge in order to communicate effectively.

Jackson (2005) states that to make a good writing vocabulary is needed and it is important to reflect students writing. For students who lack in vocabulary, they will find the struggle and difficulties in reflecting their own writing. It is because writing is related to the grammar and the grammar is related with the writing. Moreover, Neuman and Dwyer (2009) noted that vocabulary refers to the words a learner must comprehend to have an effective communication, word in speaking (Expressive vocabulary) and word in listening (receptive vocabulary).

\section{Vocabulary Mastery}

Vocabulary Mastery is the foundation for the four macro skills (Listening, Speaking, Reading, and Writing). When students have many vocabulary, it is easy for them to interact with other people. In another word, vocabulary is the basic of your capability to think and capability to share your opinion with other people (Robinson 2001). EFL teachers should be aware of students' ability in comprehending word usage as they learn foreign language; hence, when the teachers give the new words to the students, they need to give the meaning and explain the words first. So, when teachers use the words to teach foreign language, students able to comprehend (Flohr 2010).

According to Erkaya and Drower (2012) one of the great importance components to learn language is vocabulary mastery. It means that vocabulary is very vital to know in learning the English. Michelle (2010) accentuated that vocabulary is an integral part of reading comprehension. It means that teachers must be able to find the effective strategy 
to teach reading, in order to help their students to learn and get vocabulary through reading. When students are able to master English vocabulary, it will be easier for them to understand what they have read.

\section{Classification of Vocabulary}

Folse (2008) said that vocabulary can be categorized based on the function which are called part of speech including Noun, Pronoun, Verb, Adjective. The following parts will review the aspects of vocabulary used in this research

Noun

Noun is considered as one of the open words. It contains big word that offer great meaning when used in a sentence. Noun can be classified into three part those are: common noun, proper noun, concrete noun, abstract noun, collective nouns (Freeman and Freeman, 2004).

Pronoun.

Pronoun are the words that are used to replace the noun to refer to people or things without continually repeating their names. It is divided into four types as follow: subject pronouns, object pronoun, possessive pronoun, reflexive pronouns.

Verb

William (2005) stated verbs are the words that we use to signify an action or a stage of being. Verb generally express an action, events, process activities, ect. Compete sentence must contain at least one verb.

Adjective.

Seaton (2007) stated adjective is often defined as a word which describes or gives more information about noun or pronoun. Adjective can be divided into three types based on their meaning they are: proper adjectives, quantitative adjectives, descriptive adjectives.

\section{Challenges in Improving Vocabulary Mastery}

Vocabulary Mastery is not a simple thing to do. EFL students should be able to process all elements in mastering English vocabulary. For instance, EFL students have difficulty in relating new word they learn with its function; therefore, they are not able to use that new word in spoken and written activity (Muttahidah, 2011). Nisa (2009) said the factors that affect students' learning is limited knowledge of vocabulary because they do not understand its usage and meaning. Another challenge in improving their vocabulary mastery is to have print skill and comprehension strategies. These two parts are essential 
to integrate process of mastering vocabulary. If they have print skills, they are able to have good comprehension.

Having all challenges or difficulties in mastering vocabulary, most likely, will lead EFL learners to lose interest and motivation in learning. At the end, students will experience low intelligence quotient (IQ) as they learn English (Tanjung, 2011).

\section{Related Studies}

In Indonesia, there has been a study in Bebandem done by Gede (2013) entitled Improving Vocabulary Mastery Through Word Tree Branch Techniques at Seventh Grade students of SMPN 1 Bebandem. This study explained that teacher knows more about the situation in classroom, so teacher choose the best techniques to teach vocabulary. As Gede (2013) said, Word Tree Branch is the effective method for students in learning English Vocabulary because this method made students enthusiastic, creative, active and also made them think deeper.

In Bandung, a studywas done by Elisa (2014) entitled Improving English Vocabulary through Interactive Word Wall Method. Using method through Interactive Word Wall it is found that it had successfully improved students' vocabulary. It can see from the mean result that the students achieved. Word wall is useful to students, because it is not only unifying related terms, but also helping students in connections. Jacson, Tripp, Cox (2011).

Research in San Marcos, done by Henrichs (2011) declared that word walls are important tools that supports in learning and applying vocabulary and content with confidence and success.

\section{Word Tree Branch}

Word tree branch method is a method of development of the word, which in one word related to other words according to the keyword. According to Williams and Hannam (2009) there are many ways and methods to help children improve their vocabulary. It is important to use a variety of strategies in teaching to make it fun. It is a helpful tool in remembering a word with something familiar, for example "Bed" it can be associated with "Bed Room", "pillow", "Blanket", "Doll” etc. In this method, the researcher only need to give one keyword and the keyword will be developed by looking at other words which is related to that word. Unknowingly this method will make the students become more active and creative to look for vocabulary related to this keyword and to find the meaning of each word.

In this study, the researcher showed the result of using Word Tree Branch Method to improve student's vocabulary. Gede (2013), the result showed that the means score between Word Tree Branch and Traditional method are significantly different, it means 
that using Word Tree Branch Method is effective to enhance students' vocabulary and it is an interesting method.

Challenges of utilizing Word Tree Branch students are free to make decisions to express their understanding, can be memorable with a strong and permanent in students' memories. Students are more active and creative. To foster their sense of community and social solidarity the students need the excitement and optimistic spirit (Santoso, 2011).

\section{Interactive Word Wall}

Interactive Word Wall are words collected in an organized manner starting from the big and small letters on the wall and it is the activity in classroom as a tool to develop vocabulary. This involves the students as participants and teachers as instructors. Cooter (2007) mentioned that a word wall is a systematically organized collection of words displayed in large letters on a wall or other large display place in the classroom. It is a tool to use, not just display. Word wall is designed to promote group learning and be shared by a classroom of children.

Interactive Word wall are new words that students add about five each week in the large bulletin board and listed in alphabetical order (Brassell, 2010; Cronsberry, 2004). In another hand students will participate and make their own words creatively and students will be able to see the words on the wall from their sitting place.

\section{RESEARCH METHODOLOGY}

\section{Research Method and Design}

The method that is used in this research is quantitative method and it is a comparative study, where the researcher was to test the understanding of the students by giving the pre-test and post-test before and after the treatment. It means to find the improvement of students' vocabulary using Word Tree Branch Method and Interactive Word Wall Method. The research design is described in the following table:

\section{Research Instrument}

The instrument of this research are vocabulary test for pre-test and post-test with 40 question. The pre-test was designed to measure the ability of the students in the improving vocabulary before applying the Word Tree Branch Method and Interactive Word Wall Method. The post-test is designed to see the result of the study after applying each of the methods. The vocabulary test consisted of multiple choice questions. The book that will be used in teaching both groups is English Focus for grade VIII. 


\section{Data Gathering and Procedures}

In gathering the data and procedures, the researcher used the following steps:

\section{Pre-Test}

Pre-test for the grade $8 \mathrm{H} \& 8 \mathrm{~J}$ pupils was administered on February 10,2017 . It is consisted of 40 questions in multiple-choice form.

\section{Treatments}

After administering the pre-test, the treatment was conducted to the students in group $8 \mathrm{H}$ and group $8 \mathrm{~J}$. The material was taken from the text book prepared by the school and other material from Internet. There are several steps in exploiting the Word Tree Branch Method and Interactive Word Wall method.

\section{Table 1}

\begin{tabular}{|c|c|}
\hline WORD TREE BRANCH & INTERACTIVE WORD WALL \\
\hline Step 1 Determining what is & Step 1 Determining what is important \\
\hline important & $\begin{array}{l}\text { 1. Researcher will explain the material } \\
\text { (story/ picture) before the students }\end{array}$ \\
\hline \multirow{6}{*}{$\begin{array}{l}\text { 1. Researcher will explain the } \\
\text { material (story/ picture) before the } \\
\text { students read the story. } \\
\text { 2. Students listen to the explanation } \\
\text { and take a note to write the important } \\
\text { things from the materials. }\end{array}$} & read the story. \\
\hline & 2. Students listen to the explanation \\
\hline & and take a note to write the important \\
\hline & things from the materials. \\
\hline & Step 2 Reading Exercise \\
\hline & $\begin{array}{l}\text { 1. Researcher will distribute the focus } \\
\text { sheet } 1 \text { about the story. }\end{array}$ \\
\hline Step 2 Reading Exercise & $\begin{array}{l}\text { 2. Students will take turn to read the } \\
\text { story. }\end{array}$ \\
\hline 1. Researcher will distribute the & Step 3 Vocabulary \\
\hline focus sheet 1 about the story. & 1. Researcher divided the students into \\
\hline 2. Students will take turn to read the & groups that have been determined \\
\hline story & $\begin{array}{l}\text { 2. Students are invited to write the new } \\
\text { words on the wall and the other }\end{array}$ \\
\hline Sten & students will look up for the meaning \\
\hline & 3. Students will complete the exercise \\
\hline 1. Rese & in work sheet 2 to make sentences by \\
\hline groups & $\begin{array}{l}\text { using words have been found from the } \\
\text { story. It will be doing by individually. } \\
\text { Then students will try to remember the }\end{array}$ \\
\hline
\end{tabular}


2. Before the teacher give the activity to the students, teacher will explain first how to do the activity.

3. Students will find out the key word from the story (Besides the keyword that the teacher gave) as much as possible, after that they will find out the related word to the keyword and make it into a form of tree branch.

4. Researcher will come to each group to see their result (Explain again how to do the activity if they are still not understand).

\section{Step 4. Comprehension}

1. After the student's finish, they will find out the meaning.

2. After the meaning is founded, they will make a sentence by using the new word that they had been found.

3 . For the next activity, each students will come forward and read the sentence. Teacher will listen.

4. Next, the sentence will be submitted to the teacher to correction.

5. Researcher gives students 10 minutes to understand the meaning, because after that teacher will give a short quiz according to the word that had been found. words with the meaning by comprehend.

4. Researcher and students will discuss the answer together.

Step 4. Comprehension

1. Researcher ask the students to write a short story by their own.

2. Students will underline every vocabulary that they think it is difficult or they don't understand.

3. After they finish writing the story, students will paste the new word on the wall and other students will find out the meaning using dictionary. 4. Students will make sentences by using the words that have been found. 5. Next, the sentence will be submitted to the teacher to correction.

6. Researcher gives students 10 minutes to understand the meaning, because after that teacher will give a short quiz according to the word that had been found. 
Statistic procedure

The researcher used the statistical in analyzing the data. This research will be done by computing the data using several statistical calculations through the SPSS 16 program.

\section{RESULT AND FINDING}

Data Analysis

The result of pre-test and post-test of each group was calculated through excel and SPSS 16. It can be seen in the following table:

\section{Table 2}

Pre-Test, Post-Test, Standard Deviation and Normalized Gain

\begin{tabular}{|c|c|c|c|c|}
\hline & \multicolumn{2}{|c|}{ Word Tree Branch } & \multicolumn{2}{|c|}{ Interactive Word Wall } \\
\hline & Mean & St. Deviation & Mean & St. Deviation \\
\hline Pre-test & 42.42424242 & 9.657875741 & 59.57575758 & 9.358290128 \\
\hline Post-test & 82.90909091 & 8.757208758 & 88.42424242 & 7.973555927 \\
\hline Normalized Gain & 0.698393627 & 0.154946846 & 0.703013644 & 0.223352521 \\
\hline
\end{tabular}

It can be seen from the table above that the vocabulary improvement of students who acquire Interactive Word Wall is a little be higher than the students who acquire Word Tree Branch.

\section{Table 3}

Normality Test

\begin{tabular}{|l|c|c|c|}
\hline \multirow{2}{*}{ Group } & \multicolumn{3}{|c|}{ Shapiro-Wilk } \\
\cline { 2 - 4 } & Statistic & Df & Sig. \\
\hline WTB & .943 & 33 & .085 \\
IWW & .951 & 33 & .138 \\
\hline
\end{tabular}

According to the table above, this research used the output from the Shapiro Wilk because is the powerful normality test, as written by Razali and wah (2011). If both data have p.Value (sig) $>\alpha=0.05$ it means data is normally distributed and if the p.Value (sig) $<\alpha=0.05$ it means data is not normally distributed. Based on the data above, the data was normally distributed. It is because the significant score of gain for WTB was $0,85>0.05$ and the significant of the normalized gain for IWW was $0.138>0.05$. 
Test of Homogeneity of Variance

To see the homogeneity of population variances, the homogeneity test was done. The result of the homogeneity test can be seen on the table below:

Table 4

Homogeneity of Variance

\begin{tabular}{|c|c|c|c|}
\hline Levene Statistic & df1 & df2 & Sig. \\
\hline .615 & 1 & 64 & .436 \\
\hline
\end{tabular}

The data is homogenous if $p$-Value (sig) $>\alpha=0.05$ it means data is homogenous and if $p$-Value $(\operatorname{sig})<\alpha=0.05$ it means data is not homogenous. The result between WTB and IWW were homogenous. It is because sig $(0.436)>\alpha=0.05$.

\section{CONCLUSION}

From the result of data analysis on the pre-test and post-test, the researcher concluded that there is no significant difference between those who were taught through WTB and those who were taught IWW.

From WTB group on the pre-test it was 42.42 with standard deviation of 9.65 and the post-test was 82.90 with standard deviation of 8.75 , based on the WTB data showed that the gain for mean was 0.6983 with standard deviation 0.154 . IWW pre-test 59.57 with standard deviation 9.35 and the post-test 88.42 with standard deviation 7.973 , based on the IWW data showed that the gain for mean 0.7030 with standard deviation 0.223

\section{REFERENCES}

Barra,Carmen (2005) Working with Vocabulary. Chile. Retrieved from Internet

Brasell, D. (2010). Dare to Differentiate: Vocabulary Strategies for All Students. New York, NY: Guilford Press.

Cooter,K .S. (2007). Interactive Word Walls. Tennessee: University of Memphis.

Cronsberry, J. (2004). Word Wall: A Support for Literacy in Secondary School Classes.

Erkaya, O. R., \& Drower, I. S. (2012). Perceptions of an EI Learner on Vocabulary Development. International Journal of Special Education, 81-92.

Fitzgibbon, K. (2003). Vocabulary 5-Minute Daily Practice Series. New York: Scholastic Inc.

Folse, K. S. (2008). English Teaching Forum. United States.

Gede, G.E. Sutrasana. M (2013). Improving Vocabulary Mastery through Word Tree Branch Technique at Seventh Grade Students of SMPN 1 Bebandem in Academic 2012/2013: Bali.

Henrichs, L. E. (2011). Interactive Word Walls and Student Perceptions of Vocabulary. Texas, San Marcos: Texas State University-San Marcos. Journal of Adolescent \& Adult Literacy 52(5), 398408. 
Katemba, C., V. ; Sitompul, N., A., 2018 A Comparison of Using Diglot Weave Technique and Student Team Achievement Division on Student Vocabulary Achievement. Catalyst . Apr2018, Vol. 17, p29-36. 8p. Retrieved from:

https://web.a.ebscohost.com/abstract?direct=true\&profile=ehost\&scope=site\&authtype $=$ crawler

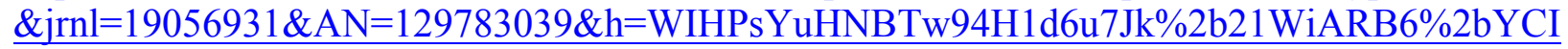
LXNBuM8t4NOh17o8Ju1 I\%2bgz\%2bZJhLhlUZtSWHonnv2stbxVowlQQ\%3d\%3d\&crl=c\&res ultNs=AdminWebAuth\&resultLocal=ErrCrlNotAuth\&crlhashurl=login.aspx $\% 3 \mathrm{fdirect} \% 3 \mathrm{dtrue} \%$ 26profile\%3dehost $\% 26$ scope $\% 3$ dsite \%26authtype\%3dcrawler\%26jrnl\%3d19056931\%26AN\%3 d129783039

KEMENDIKBUD. (2013). Standart Isi untuk Satuan Pendidikan pada Jenjang Pendidikan Dasar dan Menengah Draft ke 4. Teaching-learning handout by Pak Jaka 6th semester. Muttahiah, N (2011). Improving students' vocabulary through vocabulary card. Jakarta: Universitas Negeri Islam syarif hidayahtullah.

McKeown,M.G.L.(2002). Bringing words to Life: Robust Vocabulary instruction. New York, NY: Guilford.

Lia, Michelle, P. (2010). The effects of vocabulary instruction on the fluency and comprehension of fifthgrade nonnative English speakers Dissertation publishing Pro Quest MI U.S.A

Muttahiah, N (2011). Improving students' vocabulary through vocabulary card. Jakarta: Universitas Negeri Islam syarif hidayahtullah

Nurmayanti, I. (2013). Meningkatkan Kemampuan Vocabulary dengan Menggunakan Media Word Wall. Karawang: UNIVERSITAS SINGAPERBANGSA

Newman,S,B.,\& Dwyer, J. (2009). Missing in Action: Vocabulary Interaction in Pre-K. The Reading Teacher 384-392.

Palincsar, A.S., \& Brown, A.L (1985). Reciprocal teaching: Activities to promote "reading with your mind."

Renandya. (2002). Methodology in Language Teaching: An Anthology of Current Practice. New York. Cambridge University Press

Robinson, A. (2001). Word smart: Building an Educated Vocabulary. United States of America: The Princeton Review.

Seaton, A. (2007). Basic English Grammar for English Language Learners. United States: Saddleback Educational Publishing.

William, J.D. (2005). The Teacher's Grammar Book. London: Lawrence Erlbaum Associates, Inc. 